\title{
STRUCTURAL DESIGN FOR AIRPORT ASPHALT PAVEMENTS WITH LEAN CONCRETE BASE
}

\author{
Yoshitaka HACHIYA ${ }^{1}$ and Jianjun YIN ${ }^{2}$ \\ ${ }^{1}$ Member of JSCE, Dr. Eng., Chief, Runways Laboratory, Port and Harbor Research Institute, Ministry of Transport \\ (1-1, Nagase 3, Yokosuka 239-0826, Japan) \\ ${ }^{2}$ Dr. Eng., STA Fellow, Runways Laboratory, Port and Harbor Research Institute, Ministry of Transport \\ (1-1, Nagase 3, Yokosuka 239-0826, Japan)
}

\begin{abstract}
The process for developing a structural design method for airport asphalt pavements with lean concrete base from experimental tests was described. First, the structural and functional capabilities of the pavement structure were investigated. It was revealed that joint is the critical loading position, and that both a thicker asphalt surface course and a crusher-run subbase are beneficial. Then, the structural parameters were studied through back-calculation and calibration. By using the elastic-layered system theory, the design principle was developed considering the influence of the joint and the fatigue property of the lean concrete base. Finally, applications of the design principle were investigated.
\end{abstract}

Key Words: lean concrete, airport asphalt pavement, design, elastic-layered system, structural parameter, fatigue

\section{INTRODUCTION}

In Japan, the design method currently used for airport asphalt pavements is based on the so-called CBR method ${ }^{1)}$. The applicability of stabilized material to the base course and subbase was investigated for the first time on Nobi field tests in 1972 under the design criterion of accumulated plastic deformation on the subgrade ${ }^{2)}$. In the study, three sections with lean concrete base course were examined, and the thickness equivalency factor of the lean concrete base course was proposed, as shown in Table 1. However, these results are not yet stipulated in the design specification ${ }^{1)}$.

Because the lean concrete base course sustains most of the loads due to its high stiffness, the pavement structure could fail at the base course by insufficient flexural strength, rather than at the subgrade by excessive compressive stress. In addition, reflective cracking may also occur. Therefore, asphalt pavements with lean concrete base must be designed to prevent both flexural failure at the lean concrete base and induced reflective cracking.

This paper describes the process for developing a structural design method for airport asphalt pavements with lean concrete base from experimental tests. First, the structural and functional capabilities of the pavement structure were investigated. It was revealed that joint is the critical loading position, and that both a thicker asphalt surface course and a crusher-run subbase are beneficial. Then, the structural parameters were studied through back-calculation and calibration. By using the elastic-layered system theory, the design principle was developed considering the influence of the joint and the fatigue property of the lean concrete base. Finally, applications of the design principle were investigated.

\section{EXPERIMENTS}

Three kinds of asphalt pavements with lean concrete base were constructed experimentally. The pavements were designed under the following conditions:

1) standard aircraft: $B-747-400$

2) traffic volume: 5,000 coverages

3) subgrade CBR: $9 \%$

The pavements had both an asphalt concrete surface course and a lean concrete base course in 
Table 1 Thickness equivalency of lean concrete base ${ }^{2)}$

\begin{tabular}{c|c|c}
\hline Design compressive strength at 7 days & Manufacture method & Thickness equivalency factor \\
\hline $3 \mathrm{MPa} \leq \sigma_{7}<8 \mathrm{MPa}$ & Plant mixing & 2.0 \\
$\sigma_{7} \geq 8 \mathrm{MPa}$ & Plant mixing & 3.0 \\
\hline
\end{tabular}

Note: $\sigma_{7}=0.7 \sigma_{28}\left(\right.$ suffix: cured days) ${ }^{3)}$

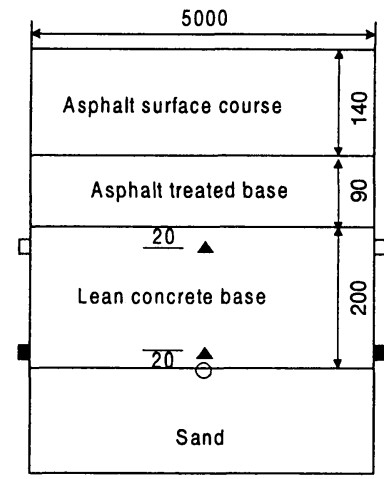

Structure A

- Soil pressure gauge

A Strain gauge

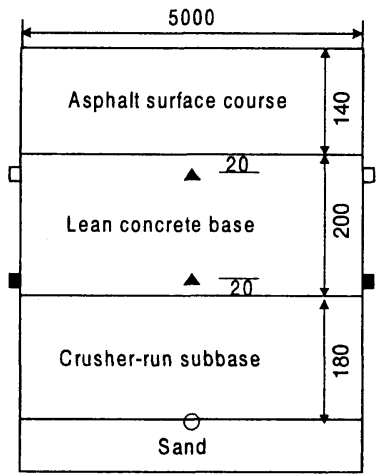

Structure B

$\square$ Joint displacement gauge (deflection)

- Joint displacement gauge (opening)

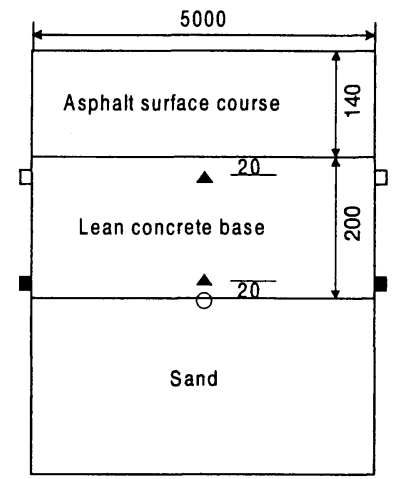

Structure C

(unit: $\mathrm{mm}$ )

Fig. 1 Experimental pavement structures

common, but their structures were different, as shown in Fig. 1. The asphalt concrete surface course was composed of a $40 \mathrm{~mm}$ thick, dense graded upper layer and a $100 \mathrm{~mm}$ thick, coarse graded lower layer. The lean concrete base course was $200 \mathrm{~mm}$ thick with a compressive strength $\left(\sigma_{28}\right)$ of $18 \mathrm{MPa}$. A $90 \mathrm{~mm}$ thick recycled asphalt treated base was used between the asphalt surface course and the lean concrete base of structure A, while a $180 \mathrm{~mm}$ thick recycled crusher-run subbase was used under the lean concrete base of structure B. Material composition of the lean concrete base is shown in Table 2. The composition of other layers was designed in accordance with the specifications for airport pavements ${ }^{4}$ ). The thickness equivalency factor was empirically taken as 3.0 for structure $A$ and $B$, and 4.0 for structure C. Soil pressure gauges, strain gauges and joint displacement gauges were installed in the experimental pavements. All sensors were calibrated before the loading tests.

Each experimental section is $5 \mathrm{~m}$ wide and $10 \mathrm{~m}$ long with a transverse joint in the middle, as shown in Fig. 2. Transverse joints must be considered because the drying shrinkage property of the lean concrete does not differ from that of normal cement concrete, as shown in Fig. 3. The drying shrinkage behaviors were observed by using the specimens in
Table 2 Material composition of lean concrete

\begin{tabular}{c|c|c|c|c}
\hline \multirow{2}{*}{ Cement } & \multirow{2}{*}{ Water } & \multicolumn{2}{|c|}{ Aggregate } & \multirow{2}{*}{ Admixtures } \\
\cline { 3 - 4 } & & Fine & Coarse & \\
\hline 195 & 152 & 867 & 1,082 & 1.95 \\
\hline \multicolumn{4}{c}{ (unit: $\mathrm{kg} / \mathrm{m}^{3}$ ) }
\end{tabular}
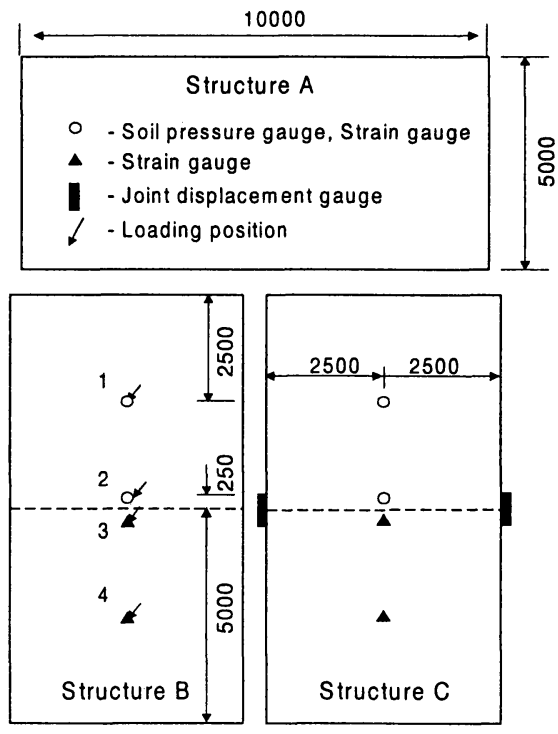

(unit: $\mathrm{mm}$ )

Fig.2 Experimental pavement sections 
Table 3 Results of plate loading tests

\begin{tabular}{c|c|c|c|c}
\hline Layer & Test item & Structure A & Structure B & Structure C \\
\hline \multirow{2}{*}{ Sand } & $\mathrm{CBR}(\%)$ & 10.6 & 10.9 & 10.0 \\
& $\mathrm{~K}_{75}\left(\mathrm{MN} / \mathrm{m}^{3}\right)$ & 60 & 72 & 58 \\
\hline Crusher-run subbase & $\mathrm{K}_{75}\left(\mathrm{MN} / \mathrm{m}^{3}\right)$ & - & 86 & - \\
\hline
\end{tabular}

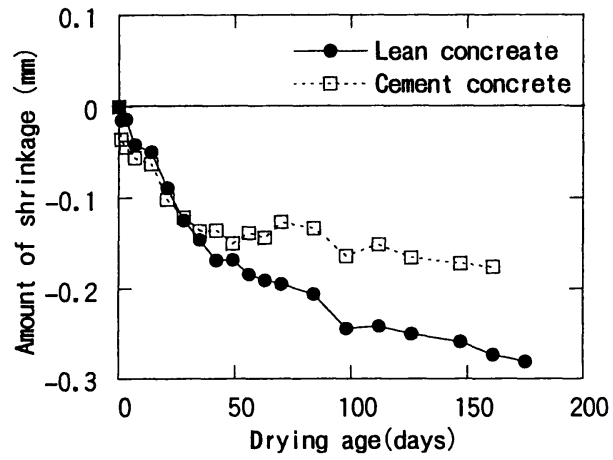

Fig. 3 Drying shrinkage property

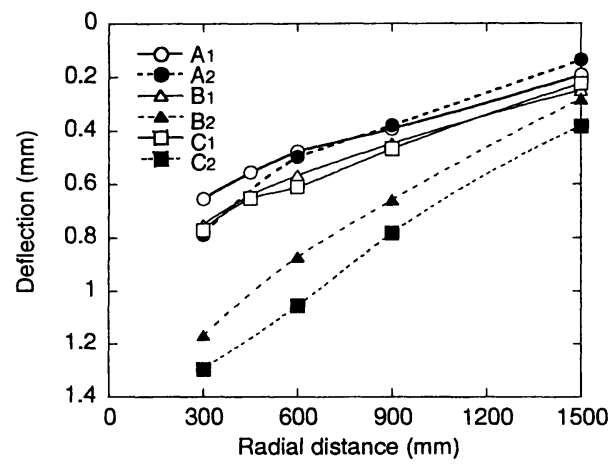

Fig. 4 Surface deflection basin (suffix: 1 - interior; 2 - joint) the laboratory, which were prepared without any differences in their circumstances to make it possible to clarify the relative difference in their drying shrinkage properties. The drying shrinkage amount was measured at the distance of $500 \mathrm{~mm}$ in the specimen of $150 \mathrm{~mm}$ wide, $150 \mathrm{~mm}$ thick and $530 \mathrm{~mm}$ long, placed on the glass beads bed.

Loading plate tests were conducted on the subgrade and subbase before the upper layer was paved. The results are listed in Table 3.

For each experimental section, static loading, repetitive loading and FWD tests were conducted in the following sequence. First, static loading tests with load amplitudes of 50,100, 150, 200, 250 and $280 \mathrm{kN}$ were conducted using a $500 \mathrm{~mm}$ diameter loading plate. Secondly, repetitive loading tests were conducted with a maximum amplitude of 250 $\mathrm{kN}$ and a frequency of $1 \mathrm{~Hz}$, also using a $500 \mathrm{~mm}$ diameter loading plate. Structure A and B received 20,000 cycles of repetitive loading, whereas 500 cycles was applied to structure C. After the repetitive loading tests, FWD tests with impulsive loads of 100,150 and $200 \mathrm{kN}$ were conducted using a $450 \mathrm{~mm}$ diameter loading plate. For all of these tests, the pavement responses, i.e., the surface deflection basin, strain in the lean concrete base and compressive stress on the subgrade, were measured. The measurement results are illustrated as follows.

\section{(1) Surface deflection basin}

Fig. 4 shows the surface deflection basin for the static loading tests with a load amplitude of $250 \mathrm{kN}$. It can be found that the surface deflection basin for the joint loading tests was generally deeper than that for the interior loading tests. This difference was most for structure $\mathrm{C}$ and least for structure $\mathrm{A}$, which indicates that structure $\mathrm{A}$ has the highest bearing capacity, whereas structure $\mathrm{C}$ has the lowest. Therefore, the pavement behavior at each joint loading case should be taken into consideration in the structural design.

\section{(2) Strain in the lean concrete base}

Fig. 5 shows the strain in the lean concrete base at the interior position in the static and repetitive loading tests with a load of $250 \mathrm{kN}$. Fig. 5(a) reveals the same phenomena as Fig. 4; that is, structure A has the highest bearing capacity, whereas structure $C$ has the lowest. It can also be found from Fig. 5(b) that section $C$ has a much larger tensile strain, whereas that of structure A remained nearly stable during the repetitive loading tests. Structure C suffered from flexural failure in the lean concrete base in the early stage of the repetitive loading test, while structure A was still in good condition at the end of the test.

\section{(3) Compressive stress on the subgrade}

Fig. 6 shows the compressive stress on the subgrade for the static and repetitive loading tests with a load of $250 \mathrm{kN}$. From Fig. 6(a), it can be 


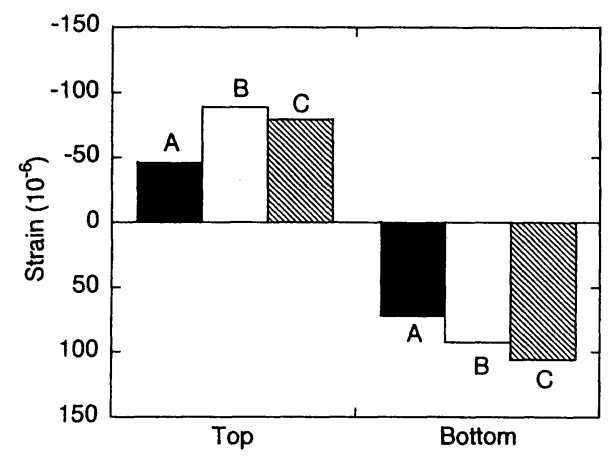

(a) Static loading

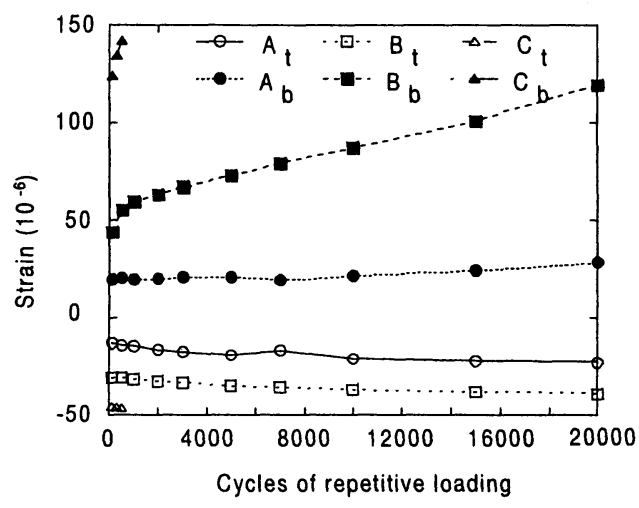

(b) Repetitive loading

Fig. 5 Strain of the lean concrete base (suffix: $t$ - the top strain gauge; $b$ - the bottom strain gauge)

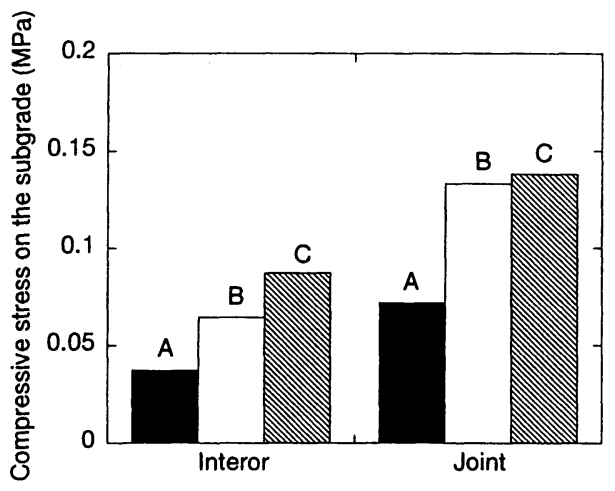

(a) Static loading

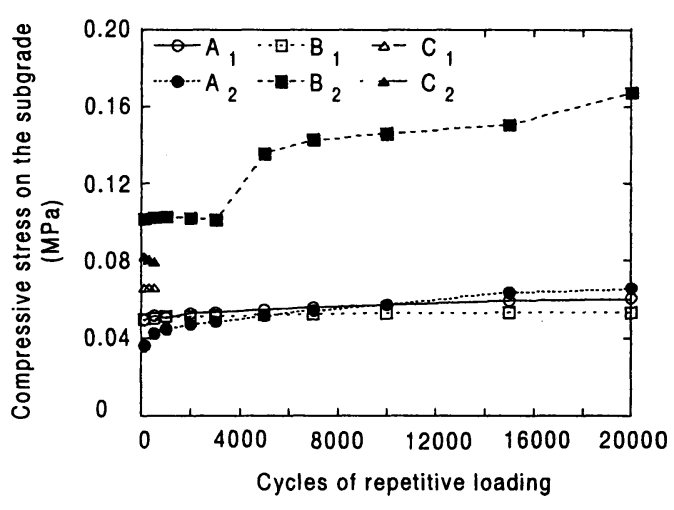

(b) Repetitive loading

Fig. 6 Compressive stress on the subgrade (suffix: 1 - interior; 2 - joint)

found that the compressive stresses for the interior loading case are much smaller than those for the joint loading, and that structure $A$ has the smallest magnitude, whereas structure $\mathrm{C}$ has the largest, especially for the joint loading case. It was revealed that the pavement structure and the loading position have a significant influence on the compressive stress on the subgrade. From Fig. 6(b), it can be found that the compressive stress of structure $B$ for the joint loading case has a tremendous increase at 4,000 cycles of loading, whereas that of structure A and that for the interior loading of structure $B$ do not have any significant increase during the repetitive loading tests. For structure $\mathrm{C}$, the stress at the interior loading case is also smaller than that at the joint loading case. Thus, from the repetitive loading test results, it was also revealed that the joint is the critical loading position.

\section{(4) Joint}

Fig. 7 shows the load transfer efficiency at the joint ${ }^{5)}$ during the static and repetitive loading tests. Magnitudes of $80 \%$ for the static loading test and over $90 \%$ for the repetitive loading test were obtained, regardless of the pavement structure. This could be because the same subgrade was used, and a similar asphalt surface course was placed on the lean concrete base course.

Both the difference in deflection and the opening at the joint were measured. As illustrated in Figs. 1 and 2 , the difference in deflection at the joint was measured by the vertical joint displacement gauges at both side of the joint whereas the joint opening was measured by the horizontal displacement gauges.

Fig. 8 shows the difference in deflection at the 


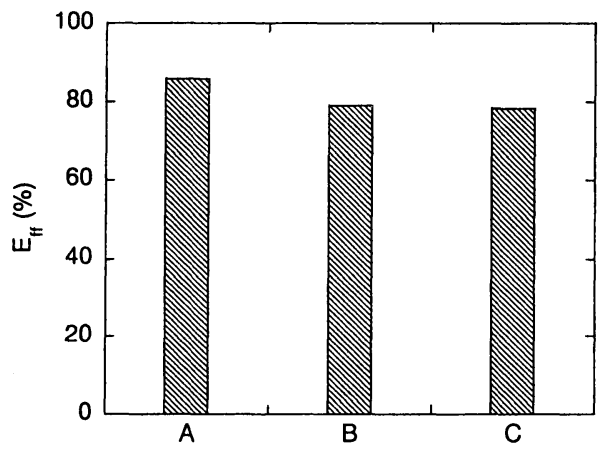

(a) Static loading

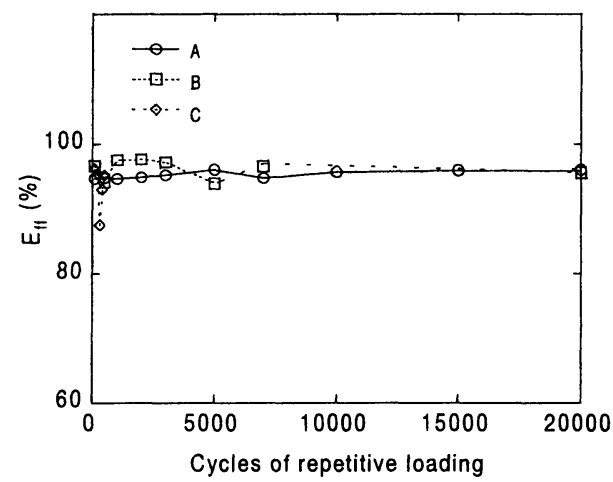

(b) Repetitive loading

Fig. 7 Load transfer efficiency

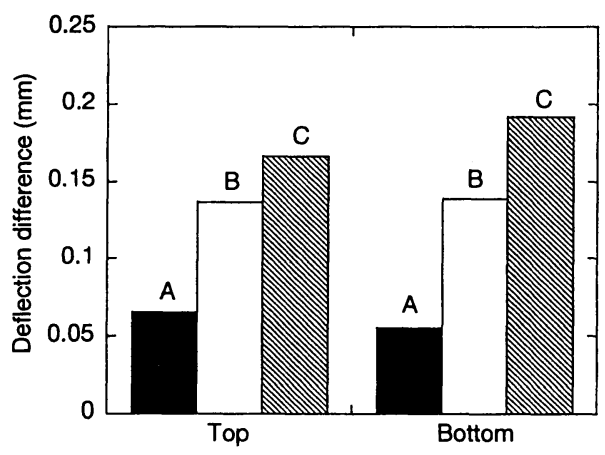

Fig. 8 Difference in deflection at joint

joint during the static loading test. Structure A has the smallest difference due to the thicker asphalt concrete layer on the lean concrete base.

Fig. 9 shows the joint opening for the FWD test with $200 \mathrm{kN}$ of impulsive load. Structure B has the smallest joint opening, suggesting that a stronger subbase course is beneficial for preventing the joint from opening.

For the structural design index, it was also investigated whether the compressive stress on the subgrade, which is the main concern for designing airport asphalt pavements in Japan, is too small to be considered for this kind of pavement structure. Consequently, the tensile strain at the bottom of the lean concrete base for the joint loading case was selected as the fundamental design index for preventing flexural failure at the base course.

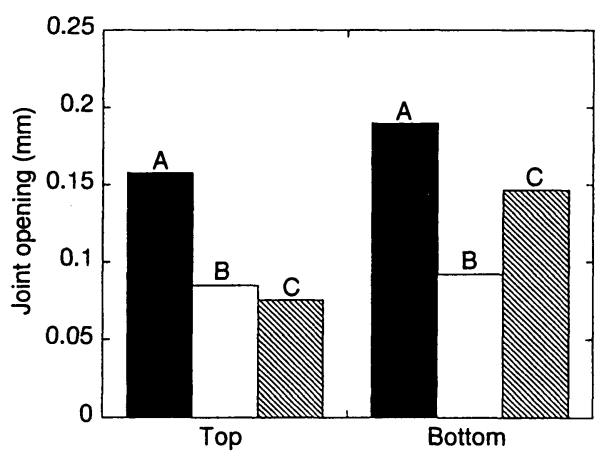

Fig. 9 Joint opening

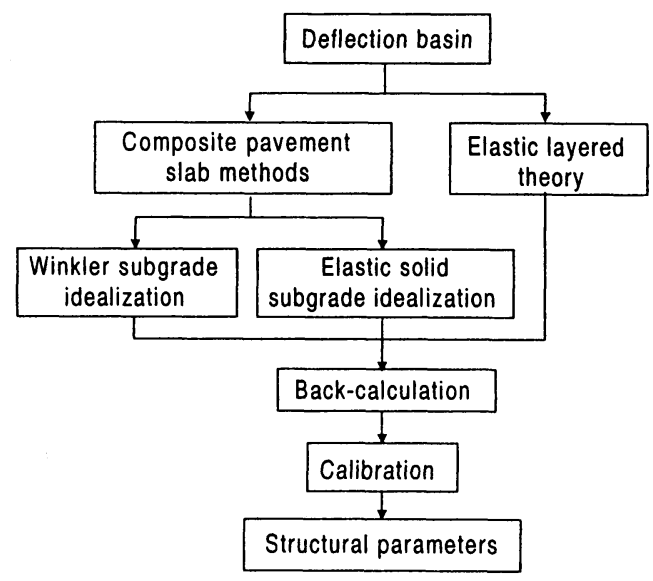

Fig. 10 Procedures for estimating the structural parameters 
Table 4 Structural parameters to calculate the tensile strain at the static loading tests

\begin{tabular}{l|c|c|c|c|c}
\hline \multirow{2}{*}{ Method } & Asphalt & Lean concrete & \multicolumn{3}{|c}{ Subgrade } \\
\cline { 4 - 6 } & layer & base & Structure A & Structure B & Structure C \\
\hline Winkler subgrade & 2,100 & 28,500 & $194^{*}$ & $114^{*}$ & $110^{*}$ \\
Elastic solid subgrade & 1,600 & 21,000 & 930 & 581 & 436 \\
Three-layered elastic system & 2,000 & 22,000 & 226 & 222 & 204 \\
\hline
\end{tabular}

unit: $\mathrm{MPa}, \quad *-\mathrm{MN} / \mathrm{m}^{3}$

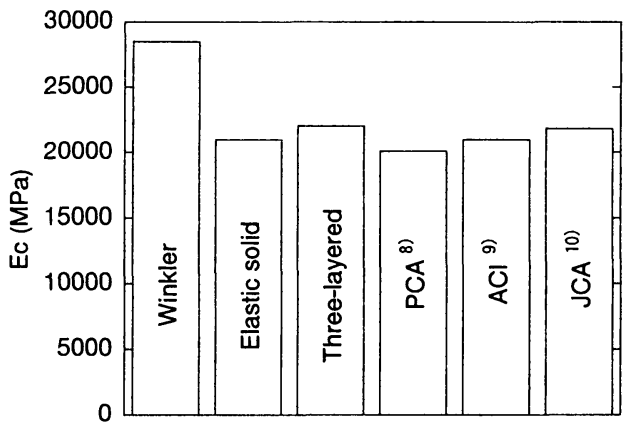

(a) Elastic modulus of the lean concrete base

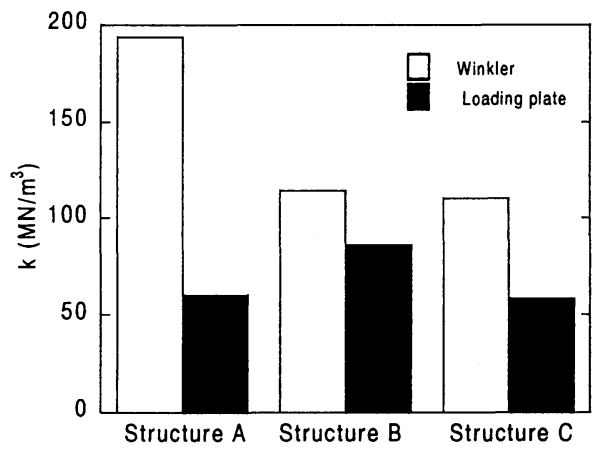

(b) Reaction coefficient of subgrade

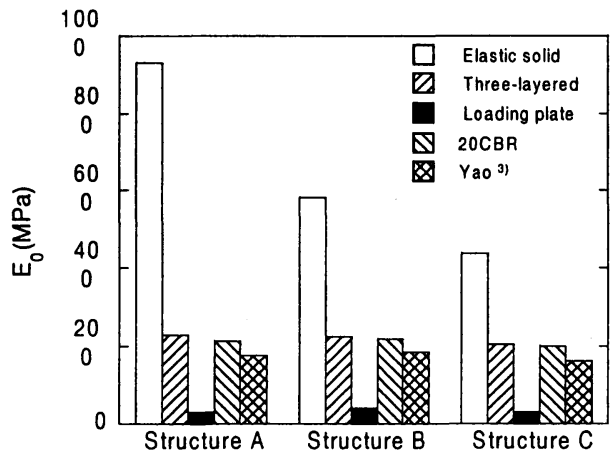

(c) Elastic modulus of subgrade

Fig. 11 Validity of the estimated structural parameters

\section{STRUCTURAL PARAMETERS}

\section{(1) Back-calculation and calibration}

The composite slab methods (namely, composite slab on Winkler and elastic solid subgrades) and the three-layered elastic system method were used to estimate the structural parameters for calculating the tensile strain of the lean concrete base course. In the procedure, the structural parameters were first back-calculated from the measured deflection basin and then calibrated to correspond to the measured strain ${ }^{6), 7)}$. The process is described in Fig. 10.

The following findings were obtained from the analysis:

1) The structural parameters back-calculated from the deflection basin by any of these methods (composite slab on Winkler or elastic solid subgrades, and the three-layered elastic system methods) significantly differ from each other.

2) The structural parameters back-calculated from the deflection basin may overestimate the tensile strain so that they cannot be directly used to estimate the tensile strain. Therefore, calibrations were conducted to correspond to the measured strain.

The structural parameters were estimated based on these findings, as shown in Table 4. Their validity is shown in Fig. 11, in which Fig. 11(a) indicates that the elastic modulus of the lean concrete base $\left(E_{c}\right)$ estimated by either the elastic 

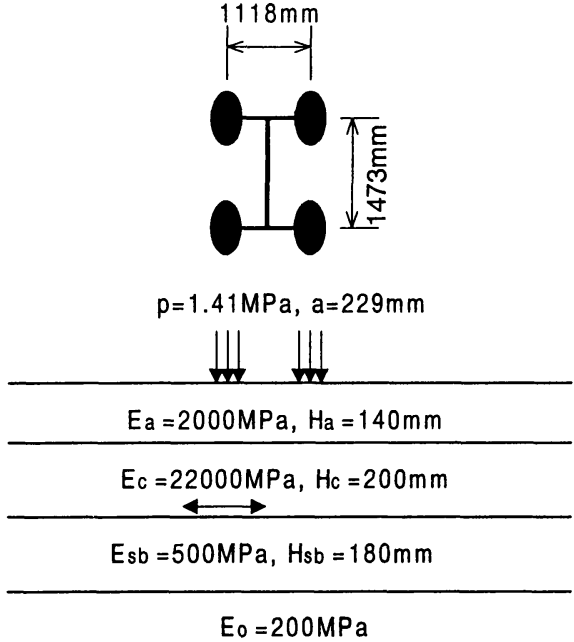

(a) Pavement structure and aircraft loading

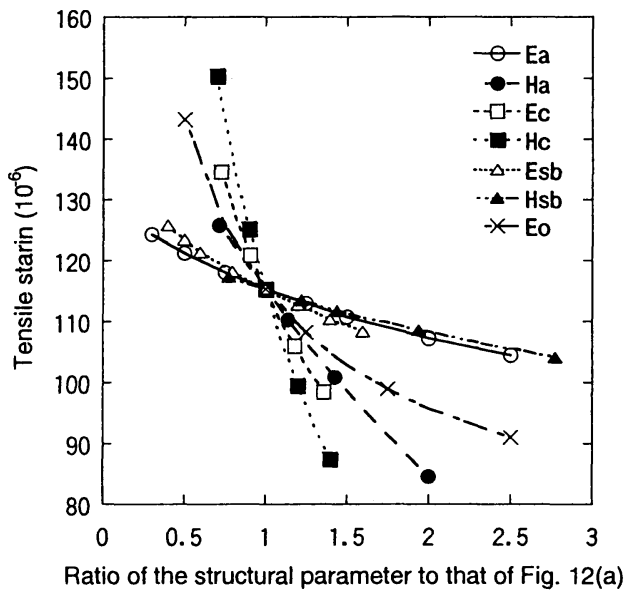

(b) Result of sensitivity analysis

Fig. 12 Sensitivity analysis

idealization or the three-layered elastic system coincides well with that reported in the literature ${ }^{8), 9), 10)}$, while that by the Winkler subgrade idealization is higher. For the subgrade, the reaction coefficient $(k)$ estimated with the Winkler subgrade idealization is larger than that measured by the plate loading test, whereas the elastic modulus $\left(E_{0}\right)$ estimated with the elastic solid subgrade idealization is extremely higher, as shown in Fig. 11(b) and Fig. 11(c), respectively. Hence, the elastic-layered system theory was introduced into the design principle.

\section{(2) Structural design parameters}

As the elastic-layered system theory was adopted, the structural parameters for pavement design were recommended as follows.

a) Elastic modulus of the lean concrete base, $E_{c}$

The ACI 318 equation ${ }^{9)}$, the validity of which is shown in Fig. 11(a), was introduced to estimate the elastic modulus of the lean concrete base, as expressed in Eq. (1)

$$
E_{c}=44 \gamma^{1.5} \sigma_{c}^{0.5}(\mathrm{MPa})
$$

in which $\gamma, \sigma_{c}$ represents unit weight (in $\mathrm{kN} / \mathrm{m}^{3}$ ), unconfined compressive strength (in $\mathrm{MPa}$ ) of the lean concrete, respectively.

b) Elastic modulus of the subgrade, $E_{0}$

Eq. (2) is introduced below. Its validity was shown in Fig. 11(c).

$$
E_{0}=20 \cdot C B R \quad(\mathrm{MPa})
$$

in which CBR represents the California Bearing Ratio of the subgrade (in \%).

c) Elastic modulus of the asphalt surface course, $E_{a}$

The following sensitivity analysis shows that the elastic modulus of the asphalt surface course has little influence on the tensile strain of the lean concrete base. Thus, a magnitude between 600 to 2,000 MPa was recommended, which may result in negligible design error.

d) Flexural strength of the lean concrete base, $f_{r}$

Eq. (3) was introduced from various equations for estimating the flexural strength of the lean concrete base ${ }^{11)}$.

$$
f_{r}=0.438 \sigma_{c}^{2 / 3} \quad(\mathrm{MPa})
$$

\section{(3) Sensitivity Analysis}

Sensitivity analysis was conducted to investigate the influence of structural parameters on the strain at the bottom of the lean concrete base beneath the center of one wheel of a B-747-400 main gear, as shown in Fig. 12(a). The elastic-layered system program BISAR was used. As shown in Fig. 12(b), the relative sensitivity to the strain is listed as follows in descending order: 
Table 5 Pavement structure

\begin{tabular}{c|c|c|c}
\hline Structure layer & Thickness $(\mathrm{mm})$ & Elastic modulus $(\mathrm{MPa})$ & Poisson's ratio \\
\hline Asphalt surface course & 150 & 700 & 0.30 \\
Lean concrete base & $t_{2}$ & $f\left(\sigma_{c}\right)$ & 0.15 \\
Crusher-run subbase & 300 & 300 & 0.30 \\
Subgrade & - & $20 . C B R$ & 0.35 \\
\hline
\end{tabular}

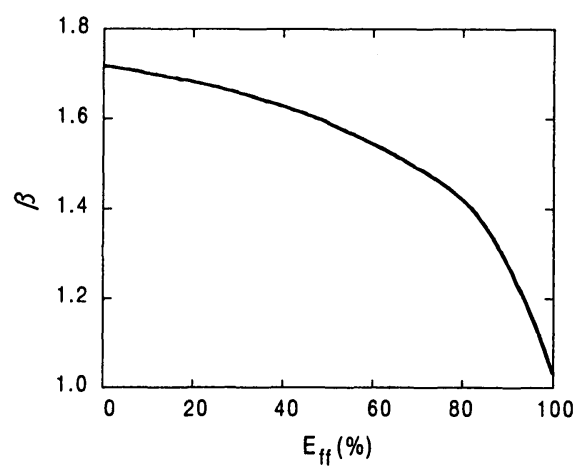

Fig. 13 Influence of the joint

1) $H_{c}$ - thickness of the lean concrete base

2) $E_{c}$ - elastic modulus of the lean concrete base

3) $E_{0}$ or $H_{a}$ - elastic modulus of the subgrade or thickness of the asphalt surface course

4) $E_{s b}$ - elastic modulus of the subbase

5) $E_{a}$ - elastic modulus of the asphalt surface course

6) $H_{s b}$ - thickness of the subbase.

Therefore, attention should be paid on the more sensitive parameters (e.g. $H_{c}, E_{c}, E_{0}$ and $H_{a}$ ) when designing the pavement structure.

\section{DESIGN PRINCIPLE}

By using the elastic-layered system theory, the design principle was developed considering the influence of the joint and the fatigue property of the lean concrete base.

\section{(1) Influence of joint}

The influence of the joint on the tensile stress is expressed by Eq. (4).

$$
\beta=\sigma_{e} / \sigma_{i}
$$

in which,

$\beta$ - the influence of the joint on the tensile stress

$\sigma_{e}$ - tensile stress for the joint loading

$\sigma_{i}$ - tensile stress for the interior loading

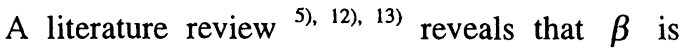

closely related to the load transfer efficiency, $E_{f f}$, as shown in Fig. 13.

\section{(2) Fatigue property}

The fatigue property of lean concrete is similar to that of either normal cement concrete or cement treated soil ${ }^{10)}{ }^{14)}$, so Eq. (5) is introduced to illustrate the fatigue property of lean concrete ${ }^{1), 10}$.

$$
\sigma / f_{r}=1-0.07 \log _{10} N
$$

where,

$N$ - loading cycles

$\sigma$ - the maximum tensile stress

$f_{r}$ - flexural strength

\section{(3) Design criterion}

Because the joint is the critical loading position, the structural design criterion was defined as follows: the tensile stress for the joint loading case should not exceed the fatigue strength of the lean concrete base. When the tensile stress was calculated for the interior loading case by the elastic- layered system theory, an equation derived by combining Eq. (4) and Eq. (5) was proposed for the structural design criterion, as expressed in Eq. (6).

$$
\sigma_{i} \leq\left(1-0.07 \log _{10} N\right) \cdot f_{r} / \beta
$$

\section{APPLICATIONS}

Applications of the structural design principle to practical design method were investigated. The standard pavement structure is considered to be composed of an asphalt surface course, a lean concrete base course and an unbound subbase, as shown in Table 5. The thickness of the asphalt surface course is determined to prevent reflective cracking, and the thickness of the crusher-run subbase is determined considering the construction procedure and cost $\left.{ }^{1)}, 4\right), 15$ ). The elastic moduli of the asphalt surface course and subbase were directly 


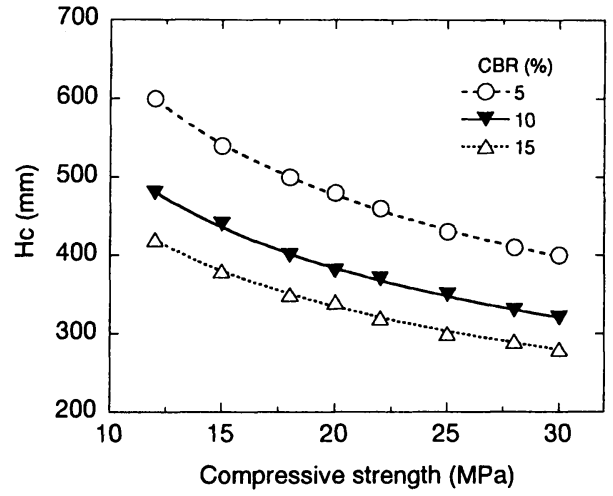

Fig. 14 Thickness of the lean concrete base with different design strength $(\beta=1.45)$

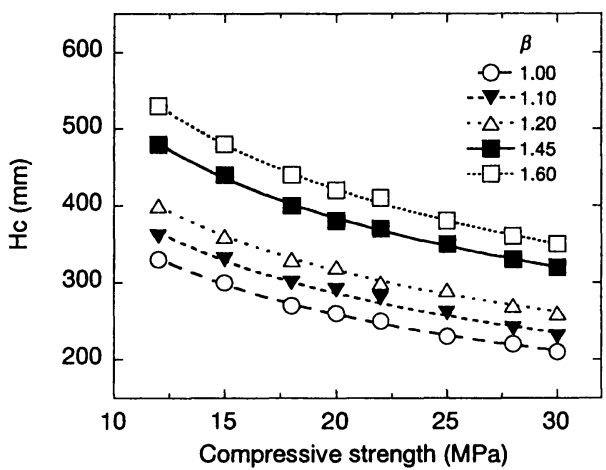

Fig. 15 Thickness of the lean concrete base with different load transfer efficiency $(\mathrm{CBR}=10)$

taken from the literature ${ }^{1)}$ because they are less sensitive to the tensile stress. Meanwhile, the analysis used a subgrade CBR of $10 \%$, the design aircraft of B-747-400 and design coverage of 20,000. Based on the static loading tests, $\beta$ was taken as 1.45 .

\section{(1) Design strength of the lean concrete base}

Design thickness of the lean concrete base is shown in Fig. 14 for different design strengths. It can be significantly reduced by increasing its design strength.

\section{(2) Load transfer efficiency}

Design thickness of the lean concrete base is shown in Fig. 15 for different load transfer efficiencies. It can be reduced significantly by improving the load transfer efficiency.

\section{(3) Thickness of the asphalt surface course}

For thickness of the asphalt surface course other

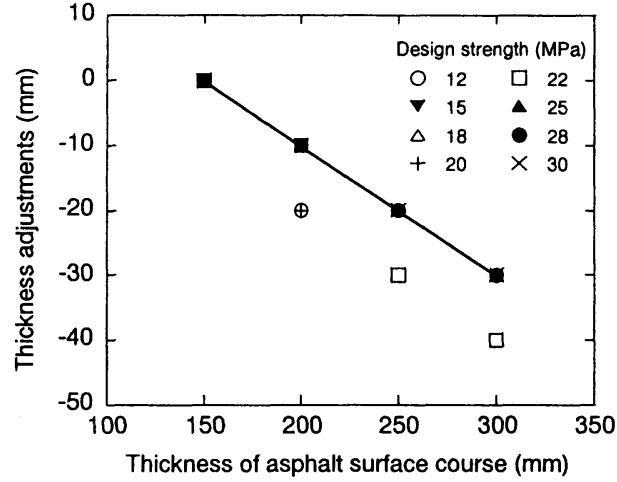

Fig. 16 Adjustments of the lean concrete base thickness to different thickness of the asphalt surface course

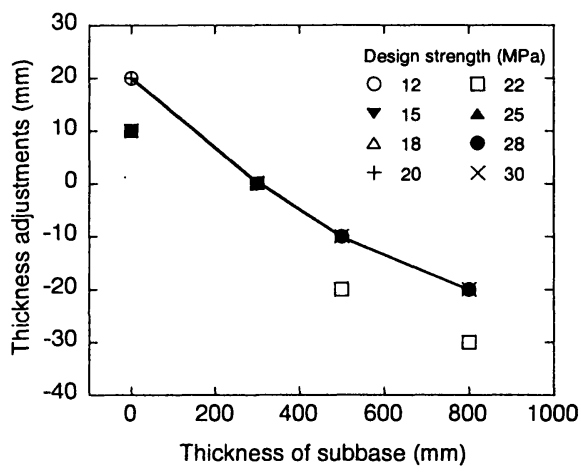

Fig. 17 Adjustments of the lean concrete base thickness to different thickness of the subbase

than $150 \mathrm{~mm}$, the thickness of the lean concrete base must be adjusted, as shown in Fig. 16. Increasing the thickness of the asphalt surface course was found to reduce the thickness of lean concrete base.

\section{(4) Thickness of the subbase}

For subbase thickness other than $300 \mathrm{~mm}$, the thickness of the lean concrete base must be adjusted, as shown in Fig. 17. It revealed that the subbase thickness has a small but constant influence on the thickness of lean concrete base, regardless of the design strength.

\section{CONCLUSIONS AND SUMMARIES}

During the development of the design method for airport asphalt pavements with lean concrete base, the following conclusions were obtained from this study:

1)The tensile stress at the bottom of the lean 
concrete base for the joint loading case was considered to be the design index for preventing flexural failure of the pavement structure at the lean concrete base.

2)A thicker asphalt surface course and a stronger subbase course are beneficial for the pavement structure from the viewpoint of pavement behavior at the joint.

3)The influence of the joint and the fatigue property of the lean concrete base were considered in the structural design. The design principle was developed as a result.

4)Design thickness of the lean concrete base mainly depends on its design strength and the load transfer efficiency at the joint. It can be adjusted to different thickness of the asphalt surface course or the subbase course.

\section{REFERENCES}

1)Civil Aviation Bureau, Ministry of Transport: Guideline on Airport Asphalt Pavement structural Design, 1990 (in Japanese).

2)Suda, H. and Sato, K.: Study on Layer Equivalencies of Bases in Airport Pavements, Report of Port and Harbor Research Institute, Vol.11, No.4, pp. 123-189, 1972 (in Japanese).

3)Yao, Z.: Cement Concrete Pavements Design, Anhui Science and Technology Press, 1998 (in Chinese).

4)Civil Aviation Bureau, Ministry of Transport: General Specifications for Airport Construction, 1993 (in Japanese).

5) Fukute, T. and Hachiya, Y.: Efficiency of Load Transfer at Joints in Concrete Pavements, Journal of JSCE, No. 343, pp. 239-246, 1984 (in Japanese).
6)Yin, J. and Hachiya, Y.: Back-calculation for Structural parameters of Pavement Slab on Winkler and Elastic Solid Subgrades, Journal of JSCE, No. 606/V-41, pp. 165-169, 1998.

7)Yin, J. and Hachiya, Y.: Estimating Structural Parameters for Flexible Composite Pavements with Lean Concrete Base, The 4th International Workshop on Design Theories and Their Verification of Concrete Slabs for Pavements and Railroads, 1998.

8)PCA: Thickness Design for Concrete Highway and Street Pavements, Washington D.C., 1984.

9)ACI Committee 318: Building Code Requirements for Reinforced Concrete (ACI 318-89) and Commentary - ACI 318R-89, ACI Manual of Concrete Practice, 1989.

10)Japan Cement Association: Report of Special Committee on Airport Pavements, pp. 45-58, 1990 (in Japanese).

11)Ahmad, S. H. and Shah, S. P.: Structural Properties of High Strength Concrete and its Implications for Precast Prestressed Concrete, PCI Journal, 30(6), pp. 92-119, 1985.

12)Chou, Y. T.: Rigid Pavement Design for Roads and Streets Elastic Layered Method, Third International Conference on Concrete Pavement Design and Rehabilitation, Purdue Univ., pp. 267-278, 1985.

13)Barker, W. R.: Introduction to a Rigid Pavement Design Procedure, Second International Conference on Concrete Pavement Design, Purdue Univ., pp. 135-148, 1981.

14)Packard, R. G.: Structural Design of Concrete Pavements with Lean Concrete Lower Course, Second International Conference on Concrete Pavement Design, Purdue Univ., pp. 119-131, 1981.

15)Civil Aviation Bureau, Ministry of Transport: Guideline on Airport Pavement Rehabilitation, pp. 95, 1984 (in Japanese).

(Received August 13, 1998)

\title{
貧配合コンクリート路盤を有する空港アスファルト舗装の構造設計
}

\section{八谷好高・殷 建軍}

\begin{abstract}
本論文では, 筫配合コンクリート路盤を有する空港アスファルト舗装の構造設計法について, 試験舗 装を用いた開発過程を論じている。まず, 試験舗装の構造的・機能的特性について検討し，その結果と して，筫配合コンクリート路盤の目地部載荷がクリティカルであること，路盤上の厚いアスファルトコ ンクリート層とその下方の粒状下層路盤を用いることが構造上有利であることがわかった. 次に, 構造 設計時のパラメータについて試験データを逆解析することにより推定し，実測值と対比することによっ て検証した。そして，多層弾性理論を用いて，目地部載荷，コンクリートの疲労性状等を考慮した構造 設計の方針を明らかにし，最後にその適用性について検討した。
\end{abstract}

